\title{
Communicative action seeking golden years!
}

Thereza Maria Magalhães Moreira ${ }^{1}$

Over the year of 2015 much has been said and celebrated about the 15 years of Rene.

Profesor Lorita Pagliuca, the journal's founder and my first counselor in research, in the editorial number one, brilliantly rescued, based on the doctor Saramago's work, that "utopia is the spice of life" and warned that social responsibility preserves the affection and inclusive do over the magazine's evolution ${ }^{(1)}$.

Professor Vera Leitão, former editor in chief of Rene, in the editorial number two, wisely said about the developments experienced by Rene in this 15 years, as currently the magazine is bilingual, bimonthly, available electronically, with greater visibility in national and international indexes, with relevant articles and participation of renowned researchers, including foreign ${ }^{(2)}$.

Professor Marli Galvão, current editor in chief of Rene, in the editorial number three, rescued the historical aspects of the journal, highlighting the gradual increase of magazine's issues from two to six per year, the acquisition of Digital Object Identifier (DOI) and the current articles' disclosure from all over Brazil and even abroad. She also commented accurately on the challenge of self-financing and the search for other sources of support $^{(3)}$.

Professor Nazaré Fraga, also a former editor in chief of Rene, in the editorial number four, wisely commented about the difficult mission which was to create, operate, grow and become victorious the then new journal. In addition, she criticized the scant (nonexistent?) resources' guidance for funding of nursing journals coming from the Northeast ${ }^{(4)}$.

And finally, in the editorial number five, Professor Alacoque Erdmann, section editor, congratulated the Graduate Program in Nursing at the Nursing Department and the institution Federal University of Ceará, Rene's home. Also highlighted the inclusion of the journal in the Cumulative Index to Nursing and Allied Health Literature (CINAHL), in the Bibliographic database of the Foundation Index (CUIDEN), Virtual Health Library (VHS), Nursing Journals Portal (Rev@Enf), Latin American and Caribbean Health Sciences (LILACS), Latin American Index of Science Journals (PERIÓDICA), Regional Information System for Online Scientific Journals of Latin America, Caribbean, Spain and Portugal (LATINDEX), EBSCO publishing, Scientific Journals of Latin America and Caribbean, Spain and Portugal (REDALYC) and Journals Portal CAPES ${ }^{(5)}$.

Faced with so good reviews and so many celebrations, What I have left to comment? There is no doubt about the growth and maturation of the journal over its 15 years, which has been very well explained by my predecessors.

I thought, then, to make the analogy of Rene's life with the human being, as when a baby is born, there is a whole excitement surrounding. There are many visits, many gifts and many people willing to help. With its growth, life runs its course and there is some accommodation. New excitement takes shape every birthday and especially to complete 15 years and debut for life.

So, the first 15 years of life go very fast because there is a lot to live and to discover. Suddenly, we got to 15 years of Rene! New stage of life to unfold. That initial excitement began to security, in-depth knowledge and the scope of good and faithful life partners. There is still much to learn, because life is just beginning ... Make 15

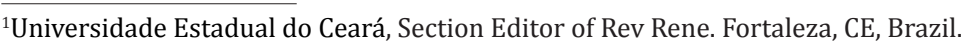

Corresponding author: Thereza Maria Magalhães Moreira

Rua Osvaldo Cruz, 1772 - Apto 1002 - Aldeota. CEP: 60125-150 - Fortaleza, CE, Brazil. E-mail: tmmmoreira@pq.cnpq.br 
years is to use with sense much of what we learn. So, 15 years marks the lives of all - human being and Journal, which leads us to reflection.

I recognize all the achievements in these 15 years. I have a scientific and emotional bonds with the Journal - I like, I want well, I help to take care of ... So, dear Rene, I wish that a new world is open for you in this 15 years, a world full of beautiful things and a lot of happiness!

The philosopher Jürgen Habermas argues, as a proposal for society, that we gradually change from the strategic action (individualistic) to the communicative action (guided to mutual understanding) ${ }^{(6)}$. So let's do it with Rene! Having a strong northeastern journal in Nursing not only strengthens the Federal University of Ceará, but the entire Northeast and Brazilian's nursing.

Let us take the joy of the 15 years celebration, Rene, for in mutual understanding - Journal and Brazilian Nursing - seek to act communicatively toward its golden years. Bring more years to come! Congratulations, Rene!

\section{References}

1. Pagliuca LMF. 15 anos da Rev Rene [Editorial]. 2015; 16(1)1-2.

2. Cardoso MVLML. Percorrendo caminhos: aniversário de 15 anos da Rev Rene [Editorial]. 2015; 16(2)141-2.

3. Galvão MTG. Rev Rene celebrando 15 anos: construindo sonhos [Editorial]. 2015 16(3):294-5.

4. Fraga MNO. Rev Rene completa 15 anos: vitórias e novos desafios [Editorial]. 2015 16(4):460.

5. Erdmann AL. 15 anos da Rev Rene - um tributo para a Enfermagem Brasileira! [Editorial]. 2015; 16(5):6223.

6. Habermas J. The Theory of Communicative Action: Reason and the Rationalization of Society. Cambridge: Polity Press; 1986. 